\title{
Inhibition of Bacterial Wilt of Tomato Caused by Ralstonia solanacearum by Sugars and Amino Acids
}

\author{
Marylene Bagarinao Posas ${ }^{1 *}$, KoKI TOYOTA $^{1}$, and TAJUl MD ISLAM ${ }^{1}$ \\ ${ }^{1}$ Graduate School of Bio-Applications and Systems Engineering, Tokyo University of Agriculture and \\ Technology, 2-24-16, Naka-cho, Koganei City, Tokyo 184-8588, Japan
}

(Received February 14, 2007-Accepted June 7, 2007)

Different sugars and amino acids were added to a conducive soil to study their effects on bacterial wilt of tomato caused by Ralstonia solanacearum YU1Rif43. The compounds were selected mainly based on the utilization ability of the pathogen and added to the soil at application rates of 0.5 to $5 \mathrm{mg} \mathrm{g}^{-1}$, together with an inoculation of the pathogen. While tomato seeds germinated and grew healthy in soils amended with carbohydrates at a rate of $5 \mathrm{mg} \mathrm{g}^{-1}$, most of the seeds failed to germinate in soils to which serine, glycine and alanine were applied at the same rate. At $2.5 \mathrm{mg} \mathrm{g}^{-1}$, the inhibitory effect on tomato germination disappeared except for methionine. Most of the compounds decreased the incidence of wilt during 30 days of cultivation, while sucrose, fructose, threonine, acetate, and glycerol had no apparent suppressive effect. The compounds that showed the most suppressive effect were glucose, proline, glutamine, serine, arginine, and lysine. The pathogen utilized glucose, proline, and glutamine, but not serine, arginine and lysine. Certain compounds stimulated microbial activity and decreased the survival of the pathogen, and thereby suppressed bacterial wilt of tomato.

Key words: dehydrogenase, glucose, microbial activity, lysine, survivability

Ralstonia solanacearum is a widely distributed plant pathogenic bacterium in the tropical, sub-tropical and warm temperate zones of the globe ${ }^{3)}$. Available methods for controlling bacterial wilt include crop rotation, use of resistant varieties, grafting on root stocks, disinfection of plant materials, etc ${ }^{7}$. Although various control measures have been documented, bacterial wilt is still a major threat to tomato production, because of its wide host-range and better survival of its pathogen in soil, especially in deeper layers ${ }^{7}$. Since the pathogen attacks the plant from the soil, it is difficult to control the disease using commercially available agrochemicals. Therefore, alternative control methods are deemed essential for the management of bacterial wilt.

Certain composts used as a soil amendment or in container media may protect plants from diseases caused by soil-borne plant pathogens ${ }^{4}$. As for the bacterial wilt of tomato caused by $R$. solanacearum, it is reported that the

\footnotetext{
* Corresponding author. E-mail address: kokit@cc.tuat.ac.jp; Tel. \& Fax: +81-42-388-7915.
}

disease incidence was suppressed in soils amended with cow manure ${ }^{14,17)}$ and household compost $^{18)}$. Islam and Toyota $^{10)}$, revealed that pre-incubation at low temperature and lower soil moisture conditions reduced survival of the bacterial pathogen, which consequently resulted to a decrease in bacterial wilt disease. Our previous report ${ }^{11)}$ also suggested that bacterial wilt of tomato was suppressed by certain composts that promoted microbial activity, due to their higher contents of water soluble C and N. Simple organic compounds like sugars and amino acids are readily decomposed by soil microbes contributing to the increase in microbial activity.

Indeed, Okamura et al. ${ }^{15)}$ reported that the density of $R$. solanacearum in soil was markedly reduced by adding simple organic compounds that are not utilized by the pathogen, such as serine and glycine. In contrast, Matsuoka et al. ${ }^{12)}$ found that the addition of glucose, utilizable by the pathogen, to a pumice culture increased its suppressiveness to bacterial wilt of tomato. The objective of this study was to explore the ability of different kinds of simple sugars and 
amino acids based on suppression of tomato bacterial wilt and to analyze possible suppressive mechanisms.

\section{Materials and Methods}

\section{Soils}

Surface soils ( 0 to $10 \mathrm{~cm}$ ), named CF-soil (fertilized with chemical fertilizer only for more than $14 \mathrm{y}$ : $\mathrm{pH}\left(\mathrm{H}_{2} \mathrm{O}\right)$ : 4.3, total $\mathrm{C}$ and $\mathrm{N}$ : 8.9 and $1.1 \mathrm{~g} \mathrm{~kg}^{-1}$ ) and $\mathrm{CF}+\mathrm{FYM}$-soil (fertilized with chemical fertilizer and $40 \mathrm{t} \mathrm{ha}^{-1}$ of farmyard manure for more than $14 \mathrm{y}: \mathrm{pH}\left(\mathrm{H}_{2} \mathrm{O}\right): 5.5$, total $\mathrm{C}$ and $\mathrm{N}$ : 20.5 and $2.2 \mathrm{~g} \mathrm{~kg}^{-1}$ ) were collected from the Nagoya University farm (Togo-cho, Aichi-pref., Japan). The CF- and $\mathrm{CF}+\mathrm{FYM}$-soils were considered to be conducive to bacterial wilt in an inoculation study ${ }^{10}$ and some properties of the soils were previously reported ${ }^{22)}$. Three other soils were collected: from Esashi-city in Iwate-pref. $\left(\mathrm{pH}\left(\mathrm{H}_{2} \mathrm{O}\right)\right.$ : 6.3, total $\mathrm{C}$ and $\mathrm{N}: 11.0$ and $1.2 \mathrm{~g} \mathrm{~kg}^{-1}$ ), from the Koganei campus of Tokyo University of Agriculture and Technology ( $\mathrm{pH}$ $\left(\mathrm{H}_{2} \mathrm{O}\right)$ : 6.2 , total $\mathrm{C}$ and $\mathrm{N}: 60.2$ and $\left.4.5 \mathrm{~g} \mathrm{~kg}^{-1}\right)$ and from Miura-city in Kanagawa-pref. $\left(\mathrm{pH}\left(\mathrm{H}_{2} \mathrm{O}\right): 6.5\right.$, total $\mathrm{C}$ and $\mathrm{N}$ : 67.2 and $4.7 \mathrm{~g} \mathrm{~kg}^{-1}$ ). The soils were sieved through a 2 -mm screen and kept in a cold room $\left(10^{\circ} \mathrm{C}\right)$ prior to use. Several characteristics of the soils were previously reported $^{10,13,22)}$.

\section{Incidence of wilt in soil to which various organic compounds were added}

Organic compounds (starch, chitin, glucose, sucrose, fructose, xylose, sodium acetate, different amino acids: Wako chemicals, Japan) were added to $100 \mathrm{~g}$ of soil at a ratio of $0.5,1,2.5$, and $5 \mathrm{mg} \mathrm{g}^{-1}$ soil and mixed thoroughly. Then, $0.32 \mathrm{~g}$ of calcium carbonate $\left(\mathrm{CaCO}_{3}\right)$ was added to $\mathrm{CF}$-soil to raise its $\mathrm{pH}$ from 4.3 to 6.0. The compound-soilmixture was immediately inoculated with the pathogen, described below, at a density of $10^{6}$ colony forming units (CFU) $\mathrm{g}^{-1}$ soil, and adjusted to $45 \%$ of maximum waterholding capacity (MWHC) except for Koganei and Miura soil with MWHC adjusted to 55\%. Then the soil was divided into two parts: $80 \mathrm{~g}$ was put in a plastic cup $(6.6 \mathrm{~cm}$ in diameter and $4.5 \mathrm{~cm}$ in height; Agri-pot: Kirin 20 Beer Co., Ltd., Japan) for the tomato growth test and $20 \mathrm{~g}$ was put in a $50 \mathrm{ml}$ glass bottle for monitoring the survivability of the pathogen. After two weeks of incubation at $28^{\circ} \mathrm{C}$, tomato seeds were transplanted into the plastic cup as described below. In this study, fourteen days after inoculation (DAI) corresponded to 0-day after seeding.

The strain used for the inoculation was $R$. solanacearum YU1Rif43 (a mutant spontaneously resistant to rifampicin)
(Toyota and Kimura, 1996). The bacterial inoculum was prepared by overnight culture at $28^{\circ} \mathrm{C}$ in $10^{-1}$ strength of nutrient broth (Eiken Co. Ltd, Japan). The concentration of the inoculum was adjusted using a spectrophotometer to approximately $10^{8} \mathrm{cfu} \mathrm{ml}^{-1}\left(\mathrm{OD}_{660}=0.3\right)$. Tomato (Lycopersicon esculentum Mill. cv. Momotaro) seeds were pre-germinated in a moist Petri-dish in the dark at $28^{\circ} \mathrm{C}$ for 3 days. Six tomato seedlings were transplanted into each Agri-pot and three pots were prepared for each treatment. The lids were covered to retain constant moisture for 3 days and then opened. Tomato plants were grown in a climatron $(80 \%$ relative humidity, $30^{\circ} \mathrm{C}, 134 \mu \mathrm{mol} \mathrm{m} \mathrm{m}^{-2} \mathrm{~s}^{-1}$ (photon flux), 12:12 $\mathrm{h}$ light:dark cycle) for 30 days. Two milliliters of the diluted hyponex fertilizer (concentration in $\mathrm{mg} \mathrm{L}^{-1}$ was as follows: $\mathrm{N}$ [100], P [200], K [100], Mg [10], Mn [0.02], B [0.1]) was added twice a week to each pot to support plant growth during the entire incubation period. Pots were watered twice a day with distilled water to maintain $45 \%$ MWHC for CFsoil, CF+FYM-soil, and Iwate soil and 55\% MWHC for Koganei soil. Pots were placed in random order under the lights and rearranged every two days. The number of wilted plants was recorded at 2-day intervals until 30 days after seeding using a numerical disease rating scale of 0 : no wilt symptoms, $1: 1$ to $25 \%, 2: 26$ to $50 \%, 3: 51$ to $75 \%$ and 4 : 76 to $100 \%$ of plants showing wilt symptoms.

\section{Carbon source utilization test}

Different sugars and amino acids were evaluated as source of carbon for the growth of $R$. solanacearum YU1Rif43 (Table 1). A 24-hr old pure colony of the pathogen on $10^{-1}$ strength nutrient agar medium (1/10 NA) was picked and suspended in $1 \mathrm{ml}$ of sterile $\mathrm{NaCl}$ solution. Afterwards, a loopful of the suspension was aseptically inoculated to a sterilized liquid inorganic medium composed of $1 \mathrm{~g}$ of $\mathrm{NH}_{4} \mathrm{NO}_{3}, 1 \mathrm{~g}$ of $\mathrm{KH}_{2} \mathrm{PO}_{4}, 0.5 \mathrm{~g}$ of $\mathrm{MgSO}_{4} \cdot 7 \mathrm{H}_{2} \mathrm{O}$, and $0.2 \mathrm{~g}$ of $\mathrm{KCl}$ that was separately added

Table 1. Growth reaction of $R$. solanacearum YU1Rif43 in solutions with different organic compounds as a sole carbon source

\begin{tabular}{cl}
\hline \multicolumn{1}{c}{ Positive growth } & \multicolumn{1}{c}{ Negative growth } \\
\hline Amino acids: & \\
$\begin{array}{l}\text { Alanine, Asparagine, Aspartic } \\
\text { acid, Glutamate, Glutamine, } \\
\text { Histidine, Proline, Threonine }\end{array}$ & $\begin{array}{l}\text { Arginine, Cysteine, Glycine, } \\
\text { Leucine, Lysine, Methionine, } \\
\text { Phenylalanine, Serine, } \\
\text { Tyrosine, Valine }\end{array}$ \\
$\begin{array}{l}\text { Sugars and others: } \\
\text { Acetate, Chitin, Fructose, } \\
\text { Glucose, Sucrose }\end{array}$ & Glycerol, Starch, Xylose \\
\hline
\end{tabular}


Table 2. Effect of the addition of different organic compounds at 5 $\mathrm{mg} \mathrm{g}^{-1}$ on disease index of bacterial wilt of tomato caused by $R$. solanacearum YU1Rif43 at 30 days after seeding using CF-soil (Experiment 1)

\begin{tabular}{lc}
\hline \multirow{2}{*}{ Treatment } & Disease Index* \\
\cline { 2 - 2 } & Mean (SE) \\
\hline CF-soil & $3.56(0.27)$ \\
+Yeast extract & $1.56(0.27)$ \\
+Chitin & $0.44(0.27)$ \\
+Glucose & $0.00(0.00)$ \\
+Xylose & $0.89(0.27)$ \\
+Serine & $\mathrm{RG}$ \\
+Alanine & $\mathrm{RG}$ \\
+Glycine & $\mathrm{RG}$ \\
\hline
\end{tabular}

* Data are shown as the mean and standard error (SE) of 3 replicate pots, which contained 6 plants each.

RG: reduced germination of tomato plants.

with $5 \mathrm{~g}$ of each amino acid or sugar per liter. Growth of the pathogen was assessed after 2 to 3 days incubation at $30^{\circ} \mathrm{C}$.

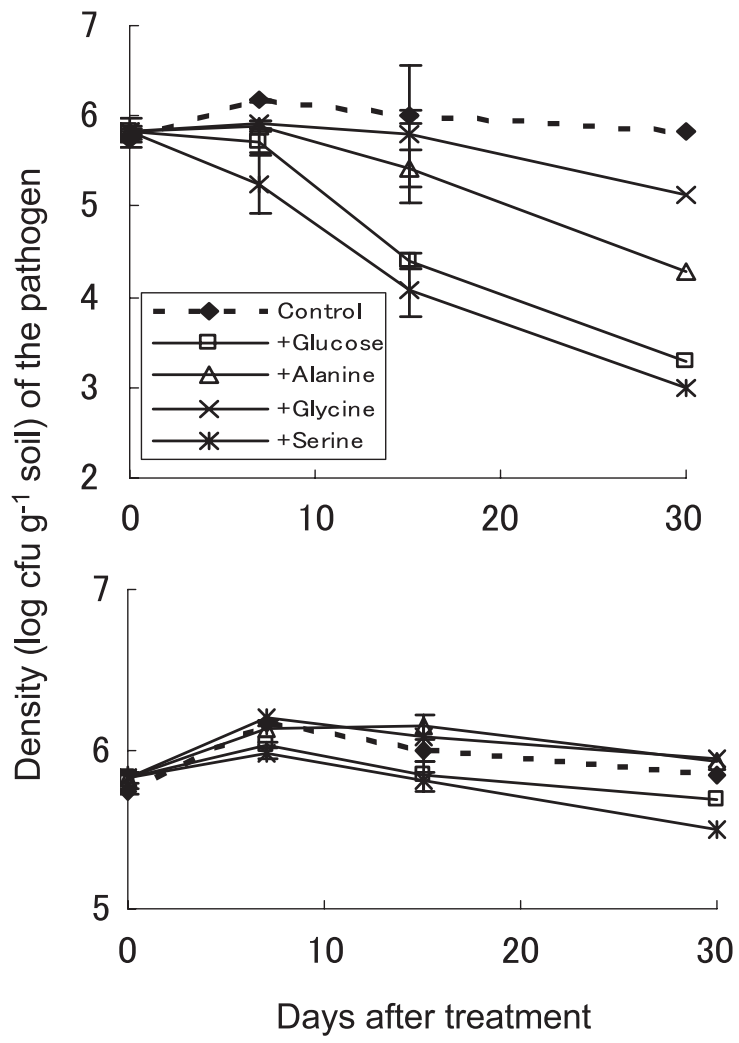

Enumeration of the pathogen and dehydrogenase activity

Culturable population of the pathogen was determined by dilution plate method using 1/10 NA containing $50 \mu \mathrm{g} \mathrm{ml}^{-1}$ rifampicin, $50 \mu \mathrm{g} \mathrm{ml}^{-1}$ polymyxin $\mathrm{B}$, and $100 \mu \mathrm{g} \mathrm{ml}^{-1}$ cycloheximide. Non-rhizosphere soil (2.0 g on a fresh basis) was periodically taken from glass bottles, described above, where tomato plants were not grown. Measurements of the population density of the pathogen were conducted in duplicate samples randomly chosen from triplicates.

Dehydrogenase activity was determined with the conventional method ${ }^{20)}$ using soils sampled at 14 or 20 days after the addition of compounds and inoculation of the pathogen.

\section{Results}

Effect of application rate of organic compounds on tomato growth, bacterial wilt, and survival of the pathogen

The addition of chitin, glucose, and xlyose to soil at an application rate of $5 \mathrm{mg} \mathrm{g}^{-1}$ soil did not affect the germination and subsequent growth of tomato seeds and these com-

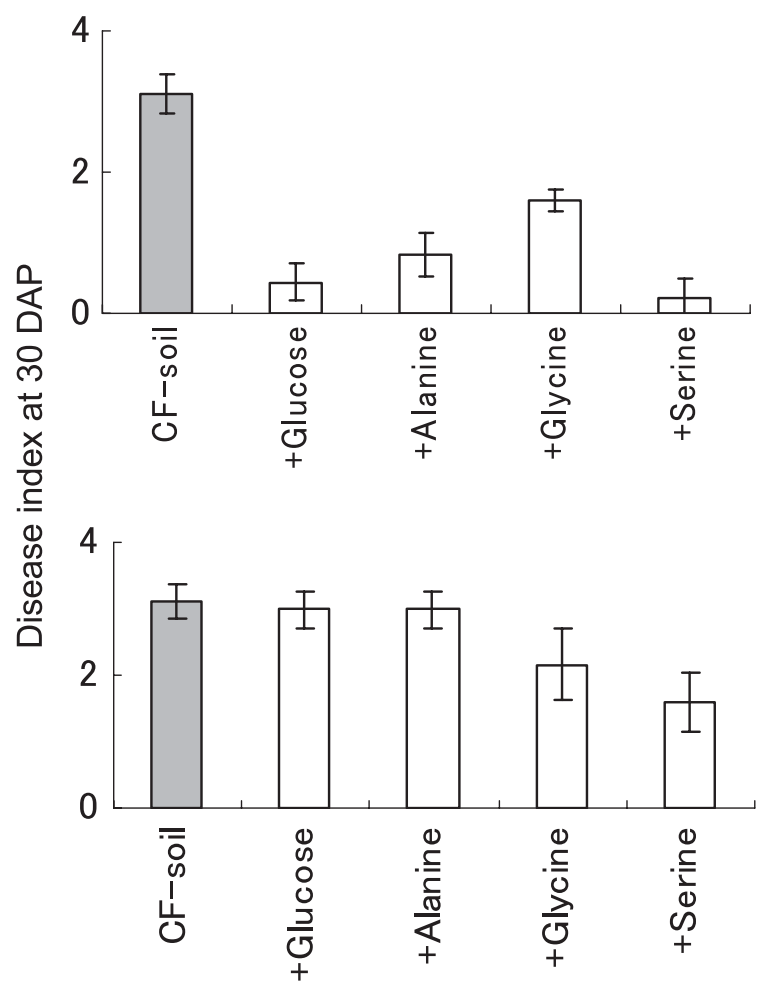

Fig. 1. Effect of different application rates of organic compounds on the dynamics of the pathogen in bulk soil and disease index of bacterial wilt of tomato (Experiment 2). Upper: application rate of $2.5 \mathrm{mg} \mathrm{g}^{-1}$, lower: application rate of $1 \mathrm{mg} \mathrm{g}^{-1}$. 
pounds decreased wilt incidence compared to the control without any addition of the organic compounds (Table 2). In contrast, more than $50 \%$ of tomato seeds did not germinate when serine, glycine, and alanine were added at an application rate of $5 \mathrm{mg} \mathrm{g}^{-1}$ soil, in spite that the soil was pre-incubated for two weeks and then seeded. However, germinated tomato seeds grew healthy and did not show any wilt symptoms. When the application rate was reduced to $2.5 \mathrm{mg} \mathrm{g}^{-1}$ soil, the inhibitory effect of serine, glycine and alanine disappeared and tomato seeds germinated normally and grew healthy. The addition of serine, glycine, alanine, and glucose decreased wilt incidence by more than $50 \%$, but their suppressive effect differed depending on the kinds of substrates added (Fig. 1). When the application rate was further reduced to $1.0 \mathrm{mg} \mathrm{g}^{-1}$ soil, the suppressive effect of most amino acids decreased, but still serine and glycine had evi- dent suppressive effect (Fig. 1). At a rate of $0.5 \mathrm{mg} \mathrm{g}^{-1}$ soil, even serine had no suppressive effect (data not shown). Consequently, the application rate of organic compounds was decided at $2.5 \mathrm{mg} \mathrm{g}^{-1}$ soil, which supported healthy tomato growth and showed higher disease suppressive effect.

Effect of different compounds on bacterial wilt, survival of the pathogen and soil dehydrogenase activity

Majority of the organic compounds showed suppressive effect to bacterial wilt, while sucrose, fructose, glycerol, acetate, threonine, tyrosine, valine, and histidine had no significant suppressive effect (Table 3 ). The compounds that exhibited the highest suppressive effect were glucose, lysine, proline, arginine, serine, and glutamine. Moreover, the bacterial wilt pathogen, $R$. solanacearum, did not utilize

Table 3. Effect of the addition of different organic compounds at $2.5 \mathrm{mg} \mathrm{g}^{-1}$ on disease index of bacterial wilt of tomato caused by $R$. solanacearum YU1Rif43 (Rs) at 30 days after seeding using different soils (Experiment 3-7)*

\begin{tabular}{|c|c|c|c|c|c|c|c|c|c|c|}
\hline \multirow{2}{*}{ Treatment } & \multicolumn{2}{|c|}{ Experiment 3} & \multicolumn{2}{|c|}{ Experiment 4} & \multicolumn{2}{|c|}{ Experiment 5} & \multicolumn{2}{|c|}{ Experiment 6} & \multicolumn{2}{|c|}{ Experiment 7} \\
\hline & Mean & SE & Mean & SE & Mean & SE & Mean & SE & Mean & SE \\
\hline Control (+Rs) & 2.44 & 0.55 & 3.44 & 0.31 & 3.56 & 0.55 & 2.00 & 0.00 & 3.67 & 0.41 \\
\hline Yeast extract & & & 0.83 & 0.73 & & & & & & \\
\hline Starch & & & 2.17 & 0.72 & & & & & & \\
\hline Glucose & & & & & & & 0.33 & 0.41 & 1.33 & 0.41 \\
\hline Xylose & & & & & & & 1.00 & 0.71 & 0.33 & 0.41 \\
\hline Sucrose & & & 3.03 & 0.26 & & & & & & \\
\hline Fructose & & & 2.75 & 0.55 & & & & & & \\
\hline Glycerol & & & 3.89 & 0.03 & & & & & & \\
\hline Acetate & & & 3.69 & 0.26 & & & & & & \\
\hline Serine & & & & & & & 0.00 & 0.00 & 0.00 & 0.00 \\
\hline Glutamate & & & & & 1.78 & 0.27 & & & & \\
\hline Glutamine & 0.44 & 0.27 & & & 0.00 & 0.00 & & & & \\
\hline Cysteine & 1.11 & 0.27 & & & & & & & & \\
\hline Phenylalanine & 1.08 & 0.70 & & & & & & & & \\
\hline Threonine & 3.53 & 0.29 & & & 2.00 & 0.00 & & & & \\
\hline Tyrosine & 1.67 & 0.24 & & & 2.67 & 0.47 & & & & \\
\hline Arginine & 0.44 & 0.27 & & & 0.22 & 0.27 & & & & \\
\hline Leucine & 1.11 & 0.59 & & & & & & & & \\
\hline Lysine & 0.22 & 0.27 & & & 0.22 & 0.27 & 0.00 & 0.00 & 0.00 & 0.00 \\
\hline Methionine & NG & & & & & & & & & \\
\hline Aspartic acid & & & 1.86 & 0.44 & & & & & & \\
\hline Asparagine & & & 0.89 & 0.24 & & & & & & \\
\hline Valine & & & 2.83 & 0.55 & & & & & & \\
\hline Histidine & & & 2.83 & 0.27 & 1.50 & 0.20 & & & & \\
\hline Proline & & & 0.14 & 0.24 & 0.00 & 0.00 & & & & \\
\hline
\end{tabular}

* Data are shown as the mean and standard error (SE) of 3 replicate pots, which contained 6 plants each.

NG: no germination of tomato plants. Experiment 3: C+F-soil, Experiment 4: CF-soil, Experiment 5: Iwate soil, Experiment 6: Koganei soil, Experiment 7: Miura soil. 


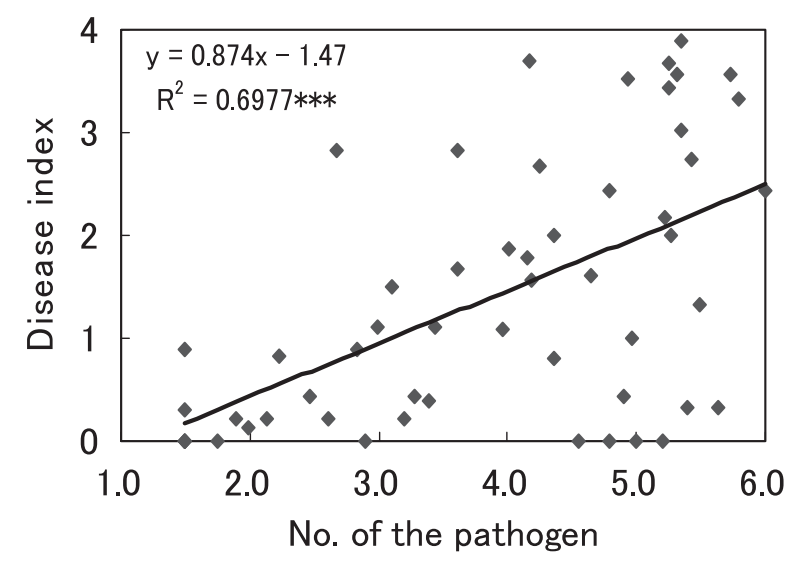

Fig. 2. Relationship between disease index of bacterial wilt of tomato and survivability of the pathogen in bulk soil. Data are derived from Fig. 1 and Experiments 3 to 7 in Table 3. *** 99.9\% significance.

arginine, serine, and lysine, but was able to utilize glucose, proline and glutamine. There was a highly significant correlation $\left(r^{2}=0.698, P<0.001\right)$ between disease index at 30 days after seeding and the survival of the pathogen expressed as density of the pathogen at 30 DAI (Fig. 2). In Experiments 3,4 , and 5 , dehydrogenase activity was measured to estimate the effect of organic compound addition on soil microbial activity (Fig. 3). In each experiment, a significant negative correlation was observed between disease index at 30 days and dehydrogenase activity at 14 or 20 days: $\mathrm{r}^{2}=0.502$, $P<0.001$ in experiment $3, \mathrm{r}^{2}=0.464, P<0.001$ in experiment $4, \mathrm{r}^{2}=0.677, P<0.001$ in experiment 5 .

\section{Discussion}

This study demonstrated that the addition of certain kinds of amino acids and glucose at a rate of 2.5 and $5 \mathrm{mg} \mathrm{g}^{-1}$ soil made soil suppressive to bacterial wilt of tomato caused by R. solanacearum YU1Rif43. Okamura ${ }^{15)}$ reported that when compounds that are not utilized by the pathogen were added to soil, the density of the pathogen in soil rapidly declined in competition with other soil microbes utilizing the compounds. Indeed, serine, xylose, lysine, and arginine are not utilized by the pathogen and thereby the addition of these compounds markedly decreased wilt incidence. However, glucose, proline, and glutamine also decreased wilt incidence in spite that these compounds are readily used by the pathogen. Disease suppression by glucose, lysine, serine, proline, arginine, and glutamine was consistently observed in two to three different soils, suggesting that this phenomenon might be general. It was concluded that certain kinds of compounds were found to suppress bacterial wilt of tomato irrespective of utility of the compounds by the pathogen after addition of such compounds to the soil. It is known that the mineralization of amino acids is highly dependent on the species and glutamate was the fastest and then glycine and lysine were the slowest in terms of mineralization rates $^{23,24)}$. In contrast, microbial assimilation efficiency (biomass production) followed the opposite series: lysine $>$ glycine $>$ glutamate ${ }^{24)}$. In our study, no test was conducted using the three amino acids in a single experiment, but lysine suppressed the incidence of bacterial wilt more effectively compared to glycine and glutamate. This could indicate that amino acids with higher microbial assimilation efficiency were more effective in suppressing tomato bacterial wilt.

Glutamate and glutamine showed contrasting results: glutamine was more effective (Table 3). Hopkins et al. ${ }^{5,6}$ ) compared metabolism between D- and L-amino acids using the substrate induced respiration (SIR) method. L-glutamine and L-glutamate showed higher rates of metabolism than the corresponding D-amino acids. There was, however, no consistent tendency in SIR of L-glutamine and L-glutamate in 5 and 12 different soils, making it difficult to estimate which amino acid was more readily decomposed. The present study showed that glutamine increased dehydrogenase activity in soil more than glutamate and thereby more increased microbial activity by the addition of glutamine might be related to more suppressive effect of glutamine to bacterial wilt.

Competitiveness of the pathogen with other soil bacteria was previously reported. When the pathogen was co-inoculated into sterile soil with individual soil bacteria, the growth of the pathogen was reduced by some competitors ${ }^{21}$. The time required for colony formation of the pathogen was 3 days, while the soil bacteria used as competitors formed colonies within 3 days, suggesting that the competitors had higher growth rates than the pathogen. This result suggested that even if compounds utilized by the pathogen are added to soil, other indigenous soil microorganisms might utilize them more efficiently than the pathogen, thereby preventing the pathogen from proliferating in the soil. Irikiin et al. ${ }^{8)}$ also revealed that competition between $R$. solanacearum and rhizobacteria for carbon sources played an important role in suppressing the growth of the pathogen. Enhanced activity of soil microbes with the addition of disease-suppressing compounds was supported by soil dehydrogenase activity, since there was a significant negative correlation between disease index and dehydrogenase activity. Increased microbial activity has been reported to be a key factor in the suppression of several soil-borne plant dis- 

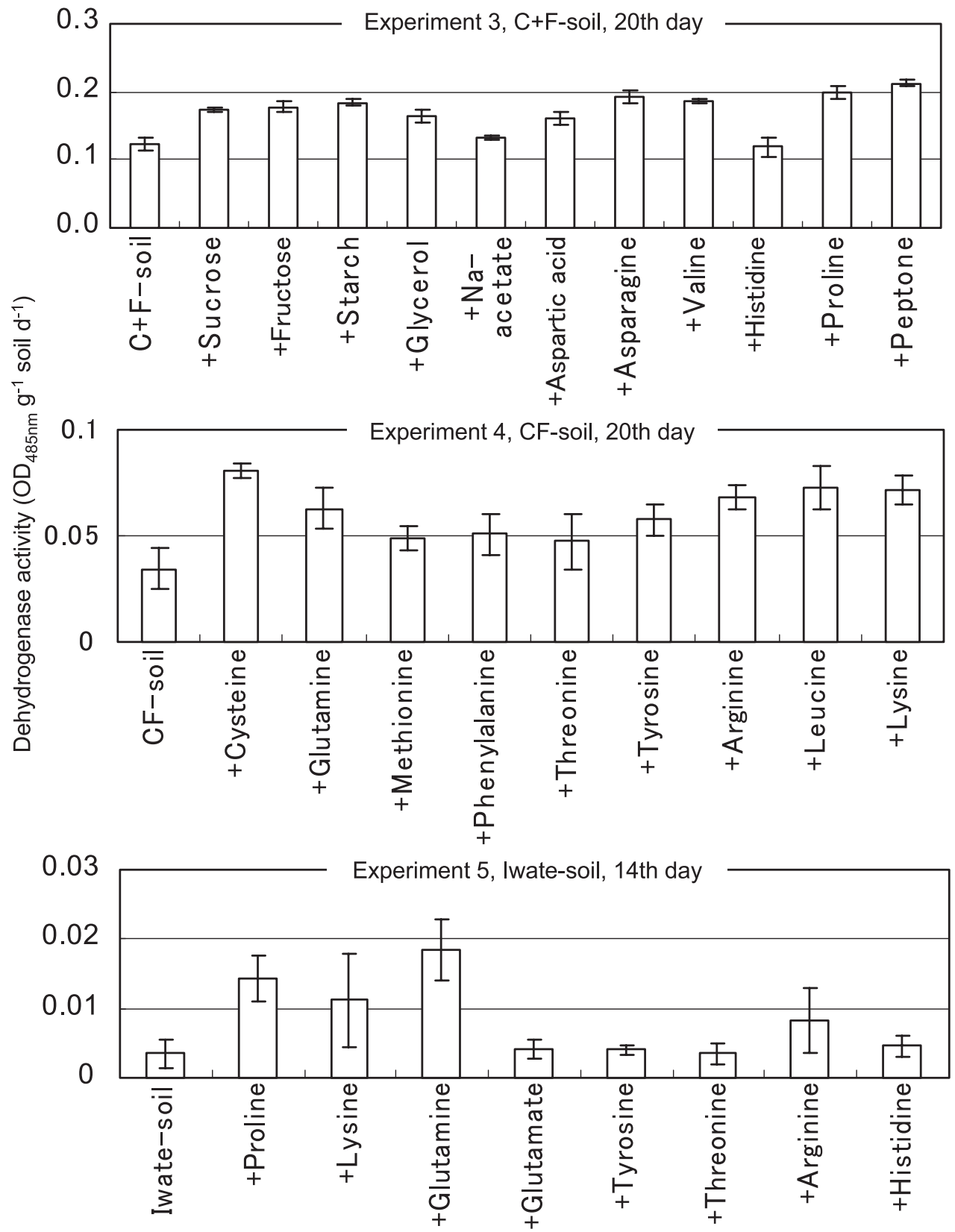

Fig. 3. Dehydrogenase activity of soils amended with different kinds of amino acids and incubated for 14 or 20 days.

eases: Fusarium wilt of flux ${ }^{19)}$, damping off caused by Rhizoctonia spp. ${ }^{2}$, and Pythium root rot of Poinsettia incited by $P$. ultimum $^{1)}$. Competition for nutrients and infection sites between these pathogenic fungi and soil microbes might play a role in disease suppression. Similarly, Olivier et $a l .{ }^{16)}$ revealed that suppression of $R$. solanacearum strain 22R6 was likely due to the activity of certain soil bacterial communities formed in response to the amendment of soil with cruciferous residues which served as source of food for indigenous soil bacteria. Our earlier report ${ }^{17)}$ also found that enhanced microbial activity with the application of certain composts might be related to a lower bacterial wilt incidence.

Dynamics of the pathogen following the addition of compounds showed a significant correlation between survivability of the pathogen and disease index, suggesting that the reduction in disease index with the addition of certain compounds could be due to a more rapid decline in the density 
of the pathogen. This reduced survival of the pathogen might be a consequence of enhanced microbial activity since there was a significant negative correlation between disease index and dehydrogenase activity.

In our previous study ${ }^{9}$, better survival of the pathogen in non-rhizosphere soil was found in a disease-conducive soil than in a suppressive soil. Additionally, it was suggested that the poor survival of the pathogen in soil habitat led to the lower disease incidence of soils added with disease suppressive composts. Furthermore, the present study supports the notion that survivability of the pathogen in soil, particularly in non-rhizosphere soil, might be a good indicator of disease outbreaks.

\section{Acknowledgements}

This research was partly supported by the project "Integrated Research for Providing Fresh and Delicious 'Brand Nippon' Agricultural-products” (61704), Ministry of Agriculture, Forestry and Fisheries, Japan, and a Research project (No. 1765) for utilizing advanced technologies in agriculture, forestry, and fisheries. The authors thank Izu, S. and Doi, S., Idemitsu Kosan Co. Ltd. and Tahara, T., Ezawa, T. and Tsuge, T., Nagoya university, for their assistance in soil sampling and information on the soil management history. Tajul Islam thanks the TUA\&T 21 Century Program (Evolution and Survival of Technology based Civilization) for financial support.

\section{References}

1) Boehm, M.J., and H.A.J. Hoitink. 1992. Sustenance of microbial activity in potting mixes and its impact on severity of Pythium root rot of poinsettia. Phytopathology 82:259-264.

2) Chen, W., H.A.J. Hoitink, A.F. Schmitthenner, and O.H. Tuovinen. 1988. The role of microbial activity on the suppression of damping-off caused by Pythium ultimum. Phytopathology 78:314-322.

3) Hayward, A.C. 1991. Biology and epidemiology of bacterial wilt caused by Pseudomonas solanacearum. Annu. Rev. Phytopathol. 29:65-87.

4) Hoitink, H.A.J., and P.C. Fahy. 1986. Basis for the control of soil-borne plant pathogens with composts. Annu. Rev. Phytopathol. 24:93-114.

5) Hopkins, D.W., B.L. Isabella, and S.E. Scott. 1994. Relationship between microbial biomass and substrate induced respiration in soils amended with D- and L-isomers of amino acids. Soil Biol. Biochem. 26:1623-1627.

6) Hopkins, D.W., R.W. O'Dowd, and R.S. Shiel. 1997. Comparison of D- and L-amino acid metabolism in soils with differing microbial biomass and activity. Soil Biol. Biochem. 29:23-29.

7) Hsu, S.T. 1991. Ecology and control of Pseudomonas solanacearum in Taiwan. Plant Prot. Bull. Taiwan 33:72-79.

8) Irikiin, Y., M. Nishiyama, S. Otsuka, and K. Senoo. 2006. Rhizo- bacterial community-level, sole carbon source utilization pattern affects the delay in the bacterial wilt of tomato grown in rhizobacterial community model system. Appl. Soil Ecol. 34:27-32.

9) Islam, T. MD, and K. Toyota. 2004. Susceptibility of soils with or without repeated application of farmyard manure to bacterial wilt of tomato caused by Ralstonia solanacearum. Soil Microorganisms 58:3-42.

10) Islam, T. MD, and K. Toyota. 2004. Effect of moisture conditions and pre-incubation at low temperature on bacterial wilt of tomato caused by Ralstonia solanacearum. Microbes Environ. 19:244247.

11) Islam, T. MD, and K. Toyota. 2004. Suppression of bacterial wilt of tomato by Ralstonia solanacearum by incorporation of composts in soil and possible mechanisms. Soil Microorganisms 19:53-60.

12) Matsuoka, T., K. Toyota, K. Sato, K. Masuda, and T. Kuroda. 2005. Suppressive mechanisms of used pumice to bacterial wilt of tomato. Soil Microorganisms 59:15-20.

13) Nerome, M., K. Toyota, T. MD Islam, T. Nishijima, T. Matsuoka, K. Sato, and Y. Yamaguchi. 2005. Suppression of bacterial wilt of tomato by incorporation of municipal biowaste charcoal. Soil Microorganisms 59:9-14.

14) Nishiyama, M., Y. Shiomi, S. Suzuki, and T. Marumoto. 1999. Suppression of growth of Ralstonia solanacearum, tomato bacterial wilt agent, on/in tomato seedlings cultivated in a suppressive soil. Soil Sci. Plant Nutr. 45:79-87.

15) Okamura, Y., N. Murakami, and W. Yagi. 2002. Hyoutekibiseibutsu no yokuseihouhou. International Patent No. WO99/ 44422.

16) Olivier, A.R., Y. Uda, S.W. Bang, H. Honjo, M. Fukami, and R. Fukui. 2006. Dried residues of specific cruciferous plants incorporated into soil can suppress the growth of Ralstonia solanacearum, independently of glucosinolate content of the residues. Microbes Environ. 21:216-226.

17) Satoh, K., and K. Toyota. 2004. Comparison of disease suppressiveness of different soils with or without repeated application of organic matters to bacterial wilt of tomato caused by Ralstonia solanacearum. Microbes Environ. 19:310-314.

18) Schonfeld. J., A. Gelsomino, L.S. van Overbeek, A. Gorissen, K. Smalla, and J.D. van Elsas. 2003. Effects of compost addition and simulated solarisation on the fate of Ralstonia solanacearum biovar 2 and indigenous bacteria in soil. FEMS Microbiol. Ecol. 43:63-74.

19) Serra-Wilttling, C., S. Houot, and C. Alabouvette. 1996. Increased soil suppressiveness to Fusarium wilt of flax after addition of municipal solid waste compost. Soil Biol. Biochem. 28:1207-1214.

20) Tabatabai, M.A. 1994. Soil enzymes, p. 775-833. In R.W. Weaver, J.S. Angle, and P.S. Bottomley (ed.), Methods of soil analysis: Part 2. Microbiological and biochemical properties. Soil Science Society of America, Inc., Madison, Wisconsin, USA.

21) Toyota, K., and M. Kimura. 1996. Growth of the bacterial wilt pathogen Pseudomonas solanacearum introduced into soil colonized by individual soil bacteria. Soil Biol. Biochem. 28:14891494.

22) Toyota, K., and S. Kuninaga. 2006. Comparison of soil microbial community between soils amended with or without farmyard manure. Appl. Soil Ecol. 33:39-48.

23) Vinolas, L.C., J.R. Healey, and D.L. Jones. 2001. Kinetics of soil microbial uptake of free amino acids. Biol. Fertil. Soils 33:67-74.

24) Vinolas, L.C., V.R. Vallejo, and D.L. Jones. 2001. Control of amino acid mineralization and microbial metabolism by temperature. Soil Biol. Biochem. 33:1137-1140. 